Al Qalam: Jurnal Ilmiah Keagamaan dan Kemasyarakatan https://jurnal.stiq-amuntai.ac.id/index.php/al-qalam

P-ISSN: 1907-4174; E-ISSN: 2621-0681

DOI: 10.35931/aq.v14i1.313

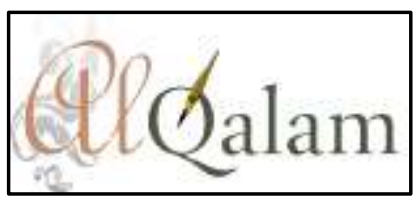

\title{
EVALUASI KINERJA PROGRAM STUDI EKONOMI SYARIAH FAKULTAS EKONOMI DAN BISNIS ISLAM IAIN SAMARINDA PASCA AKREDITASI
}

Oleh:

\author{
Yusran ${ }^{1}$, Rachmad Saleh Nasution ${ }^{2}$,
}

Dosen, Fakulas Ekonomi dan Bisnis Islam (FEBI) IAIN Samarinda 1,2 e-mail: hajiyusran75@gmai.com, ${ }^{1}$ rachmad.nasution@yahoo.com ${ }^{2}$

\begin{abstract}
This study aims to determine the perception of the IAIN lecturer at the Faculty of Economics and Islamic Business. This research method uses qualitative methods with data collection techniques such as questionnaires and data analysis using descriptive analysis. This study found that the 6 performance standards set by BANT PT, namely standard 1 about vision and mission, goals and objectives and achievement strategies, standard 2 governance, leadership, management and quality assurance systems, standard 4 human resources, and standard 5 learning curriculum and academic atmosphere, standard 6 for financing facilities and infrastructure as well as information systems, and standard 7 related to research, service and community service and collaboration in general are felt by lecturers in the satisfied or good category.
\end{abstract}

\begin{abstract}
Abstrak
Penelitian ini bertujuan untuk mengetahui persepsi dosen Fakultas Ekonomi dan Bisnis Islam IAIN. Metode penelitian ini menggunakan metode kualitatif dengan teknik pengumpulan data berupa kuesioner dan analisis data menggunakan analisis deskriptif. Penelitian ini menemukan bahwa 6 standar kinerja yang ditetapkan oleh BANT PT yaitu standar 1 tentang visi misi, tujuan dan sasaran serta strategi pencapaian, standar 2 tata pamong, kepemimpinan, sistem pengelolaan dan penjaminan mutu, standar 4 sumber daya manusia, dan standar 5 kurikulum pembelajaran dan suasana akademik, standar 6 pembiayaan sarana dan prasarana serta
\end{abstract}


Yusran, Rachmad Saleh Nasution: Evaluasi Kinerja Program Studi Ekonomi Syariah Fakultas Ekonomi dan Bisnis Islam IAIN Samarinda Pasca Akreditasi

sistem informasi, dan standar 7 terkait penelitian, pelayanan dan pengabdian kepada masyarakat dan kerjasama secara umum dirasakan oleh dosen dengan kategori puas atau baik.

Keywords: Evaluasi, Kinerja, Akreditasi, Perguruan Tinggi Islam

\section{Pendahuluan}

Salah satu unsur penting dalam pengelolaan perguruan tinggi adalah pengelolaan standar mutu pendidikan yang dilakukan secara konsisten dan berkelanjutan. Evaluasi kinerja merupakan alat yang digunakan untuk melihat apakah standar mutu yang diterapkan telah dilaksanakan oleh program studi atau fakultas dengan baik. Menurut Fahmi, kinerja adalah "hasil yang diperoleh oleh suatu organisasi baik organisasi tersebut bersifat profit oriented dan non profit oriented yang dihasilkan selama satu periode waktu". 'Secara lebih tegas Amstron dan Baron mengatakan kinerja merupakan "hasil pekerjaan yang mempunyai hubungan kuat dengan tujuan strategis organisasi, kepuasan konsumen". ${ }^{2}$ Lebih lanjutan Bastian menyatakan bahwa kinerja adalah "gambaran mengenai tingkat pencapaian pelaksanaan suatu kegiatan/ program/kebijaksanaan dalam mewujudkan sasaran, tujuan,misi dan visi organisasi yang tertuang dalam perumusan skema strategis (strategic planning) suatu organisasi. ${ }^{3}$

BAN-PT menegaskan bahwa akreditasi pada dasarnya bertujuan untuk: (1) Menjamin mutu program studi/institusi perguruan tinggi telah

${ }^{1}$ Fahmi Rahman, Manajemen Sumber Daya Manusia, (Bandung: Remaja Rosdakarya, 2009), h. 54.

${ }^{2}$ Michael Amstrong \& Baron, Manajemen Sumber Daya Manusia, terj. Sofyan dan Haryanto, (Jakarta: ElexMedia Komputindo, 2006), h. 15.

${ }^{3}$ Bastian, Pengukuran Kinerja Sektor Publik, (Yogyakarta: Bale Anugerah, 2010), h. 43 .

Al Qalam: Jurnal Ilmiah Keagamaan dan Kemasyarakatan

Vol. 14, No. 1, Januari-Juni 2020 
Yusran, Rachmad Saleh Nasution: Evaluasi Kinerja Program Studi Ekonomi Syariah Fakultas Ekonomi dan Bisnis Islam IAIN Samarinda Pasca Akreditasi

memenuhi standar yang ditetapkan (2) Mendorong perbaikan mutu program/ institusi secara berkelanjutan (3) Hasil akreditasi digunakan untuk berbagai hal seperti alokasi dana atau bantuan dari pihak luar. Hasil akreditasi dapat digunakan sebagai bahan pertimbangan dalam transfer kredit, usulan bantuan dan alokasi dana, serta mendapat pengakuan dari badan atau instansi yang berkepentingan. ${ }^{4}$

Penelitian tentang masalah-masalah yang dihadapi perguruan tinggi dalam kaitannya dengan pengukuran kualitas jasa, kinerja, penilaian dengan pendekatan akreditasi serta penilaian yang sifatnya langsung masih perlu dilakukan seiring perkembangan teknologi dan ilmu pengetahuan secara luas.

Penelitian mengenai evaluasi kinerja program studi Ekonomi Syariah adalah penelitian yang sifatnya untuk memenuhi kebutuhan internal lembaga sehingga dapat digunakan untuk perbaikan dan perkembangan lembaga ke depannya. Mengingat persaingan antar lembaga pendidikan semakin tinggi di Kalimantan Timur Khususnya Daerah Kota Samarinda.

Bertitik tolak dari latar belakang masalah di atas, maka dapat dirumuskan masalah yang akan diteliti adalah Kinerja Prodi Ekonomi Syariah pasca Akreditasi dilihat dari persepsi dosen Fakultas Ekonomi Bisnis Islam Samarinda. Untuk mengetahui persepsi dosen Fakultas Ekonomi dan Bisnis Islam IAIN Samarinda atas kinerja Prodi Ekonomi Syariah Fakultas Ekonomi Bisnis dan Islam IAIN Samarinda setelah akreditasi.

${ }^{4}$ Badan Akreditasi Nasional Perguruan Tinggi, Buku II: Standar dan Prosedur, (Jakarta: Badan Akreditasi Nasional Perguruan Tinggi, 2011), h. 1. 
Yusran, Rachmad Saleh Nasution: Evaluasi Kinerja Program Studi Ekonomi Syariah Fakultas Ekonomi dan Bisnis Islam IAIN Samarinda Pasca Akreditasi

\section{Kajian Teori}

\section{Pengertian Kinerja}

Robbins mendefinisikan kinerja pegawai dapat dilihat dalam 3 kriteria, yaitu: 1) Hasil-hasil tugas individual. Menilai hasil tugas pegawai dapat dilakukan pada suatu badan usaha yang sudah menetapkan standar kinerja sesuai dengan jenis pekerjaan, yang dinilai berdasarkan standar kinerja sesuai dengan jenis pekerjaan, yang dinilai berdasarkan periode waktu tertentu. Bila pegawai dapat mencapai standar yang ditentukan berarti hasil tugasnya baik. 2) Perilaku, perusahaan tentunya terdiri dari banyak pegawai baik bawahan maupun atasan dan dapat dikatakan sebagai suatu kelompok kerja yang mempunyai perilaku masing-masing berbeda karena itu seorang pegawai dituntut untuk memiliki perilaku yang baik dan benar sesuai dengan pekrjaan masing-masing dan 3) Ciri atau sifat, ini merupakan bagian terlemah dari kriteria kinerja yang ada. Ciri atau sifat pegawai pada umumnya berlangsung lama dan tetap sepanjang waktu, tetapi adanya perubahan-perubahan dan campur tangan dari pihak luar seperti diadakannya pelatihan akan mempengaruhi kinrja dalam beberapa hal. $^{5}$

Menurut Moehariono manajemen kinerja instansi pemerintah adalah Sebagai suatu sistem, membutuhkan suatu proses yang sistematis sehingga perlu dibuat desain sistem manajemen kinerja yang tepat untuk mencapai kinerja optimal. Sistem merupakan serangkaian prosedur, langkah atau tahap yang tertata dengan baik. Demikian juga dengan sistem manajemen kinerja organisasi publik atau instansi pemerintah 75.

${ }^{5}$ Stephen P. Robbins, Perilaku Organisasi, (Jakarta: Indeks Gramedia, 2006), h. 
Yusran, Rachmad Saleh Nasution: Evaluasi Kinerja Program Studi Ekonomi Syariah Fakultas Ekonomi dan Bisnis Islam IAIN Samarinda Pasca Akreditasi

mengandung prosedur, langkah atau tahapan yang mengandung suatu siklus kinerja. Secara garis besar, sebagai bagian dari sistem akuntabilitas kinerja, siklus manajemen kinerja dibagi dalam lima fase atau lima tahap, yaitu: perencanaan kerja, implementasi, pengukuran kinerja dan evaluasi kinerja, pelaporan kinerja, dan audit kinerja. ${ }^{6}$

Dapat disimpulkan bahwa kinerja merupakan tingkat keberhasilan keseluruhan pekerjaan selama periode tertentu dan hasil yang dicapai dari pekerjaan tersebut, yang berorientasi pada standar hasil kinerja, target atau kriteria yang telah disepakati bersama.

\section{Penilaian Kinerja}

Penilaian kinerja mempunyai peranan penting dalam peningkatan motivasi ditempat kerja. Penilaian kinerja ini (performance appraisal) pada dasarnya merupakan faktor kunci guna mengembangkan suatu organisasi secara efektif dan efisien. Pegawai menginginkan dan memerlukan balikan berkenaan dengan prestasi mereka dan penilaian menyediakan kesempatan untuk memberikan balikan kepada mereka jika kinerja tidak sesuai dengan standar, maka penilaian dapat di gunakan untuk meninjau kemajuan pegawai dan untuk menyusun rencana peningkatan kerja. Rahmanto menyebutkan prestasi kerja atau kinerja sebagai tingkat pelaksanaan tugas yang bisa dicapai oleh seseorang, unit, atau divisi, dengan menggunakan kemampuan yang ada dan batasanbatasan yang telah ditetapkan untuk mencapai tujuan instansi.

Prestasi kerja menurut Ruky di sebut juga sebagai kinerja atau dalam bahasa Inggris disebut performance. Pada prinsipnya, ada istilah

\footnotetext{
${ }^{6}$ Moehariono, Kebijakan Kinerja Karyawan, (Yogyakarta: BPFE, 2012), h. 69.
} 
Yusran, Rachmad Saleh Nasution: Evaluasi Kinerja Program Studi Ekonomi Syariah Fakultas Ekonomi dan Bisnis Islam IAIN Samarinda Pasca Akreditasi

lain yang lebih menggambarkan pada prestasi dalam bahasa Inggris yaitu kata achievement. Tetapi karena bahasa tersebut berasal dari kata to achieve yang berarti mencapai, maka dalam bahasa Indonesia sering diartikan menjadi pencapaian atau apa yang dicapai. ${ }^{7}$ Selanjutnya Hariandja juga mengemukakan bahwa kinerja merupakan hasil kerja yang telah dicapai oleh seseorang atau kelompok orang dalam suatu organisasi baik formal ataupun informal, publik maupun swasta yang sangat dipengaruhi oleh beberapa faktor yaitu kuantitas pekerjaan, kualitas Pekerjaan, pengetahuan kerja, kerjasama tim dan kreatifitas. ${ }^{8}$ Mathis dan Jackson mengatakan bahwa penilaian kinerja merupakan proses mengevaluasi seberapa baik karyawan mengerjakan pekerjaan mereka ketika dibandingkan dengan satu set standar, dan kemudian mengomunikasikan informasi tersebut. ${ }^{9}$

Menurut Sastrohadiwiryo, penilaian kinerja adalah suatu kegiatan yang dilakukan manajemen atau penyedia penilai untuk menilai kinerja tenaga kerja dengan cara membandingkan kinerja dengan kinerja atas uraian atau deskripsi pekerjaan dalam suatu periode tertentu biasanya setiap akhir tahun. ${ }^{10}$

Berdasarkan pendapat di atas dapat disimpulkan bahwa penilaian kerja merupakan suatu penilaian tentang kondisi kerja karyawan yang 2009), h. 15.

${ }^{7}$ Ahmad Ruky, Sistem Manajemen Kinerja, (Jakarta: Gramedia Pustaka Utama,

${ }^{8}$ Hariandja, Peformance Appraistal: Sistem yang tepat untuk Menilai Kinerja Karyawan dan Meningkatkan Daya Saing Perusahaan, (Jakarta: Grafindo Persada, 2005), h. 35.

${ }^{9}$ R.L Mathis \& J. H. Jackson, Human Resource Management: Manajemen Sumber Daya Manusia, Terj. Dian Angelia, (Jakarta: Salemba Empat, 2006), h. 65

${ }^{10}$ Siswanto Sastrohadiwiryo, Manajemen Tenaga Kerja Indonesia: Pendekatan Administrasi dan Operasional, (Jakarta: Bumi Aksara, 2002), h. 231. 
Yusran, Rachmad Saleh Nasution: Evaluasi Kinerja Program Studi Ekonomi Syariah Fakultas Ekonomi dan Bisnis Islam IAIN Samarinda Pasca Akreditasi

dilaksanakan secara formal dan dikaitkan dengan standar kerja yang telah ditentukan suatu instansi tertentu.

\section{Tujuan Penilaian Kinerja}

Sastrohadiwiryo mengemukakan bahwa penilaian kinerja dilakukan dengan tujuan sebagai sumber data untuk perencanaan ketenagakerjaan dan kegiatan pengembangan jangka panjang bagi perusahaan yang bersangkutan, sebagai nasihat yang perlu disampaikan kepada para tenaga kerja dalam perusahaan, sebagai alat untuk memberikan umpan balik (feed back) yang mendorong ke arah kemajuan dan kemungkinan memperbaiki atau meningkatkan kualitas kerja bagi para tenaga kerja, sebagai salah satu cara untuk menetapkan kinerja yang diharapkan dari seorang pemegang tugas dan pekerjaan, sebagai landasan/bahan informasi dalam pengambilan keputusan pada bidang ketenagakerjaan, baik promosi, mutasi, maupun kegiatan ketenagakerjaan lainnya dan sebagai standar dalam penentuan tinggi rendahnya kompensasi serta administrasi bagi tenaga kerja. ${ }^{11}$

Kemudian menurut Faustino Cardoso Gomes tujuan penilaian kinerja secara umum dibedakan atas dua macam, yaitu untuk mereward performasi sebelumnya (to reward past performance) dan untuk memotivasikan perbaikan performansi pada waktu yang akan datang (to motivate future performance improvement $).{ }^{12}$

${ }^{11}$ Siswanto Sastrohadiwiryo, Manajemen Tenaga ..., h. 233.

${ }^{12}$ Faustino Cardoso Gomes, Manajemen Sumber Daya Manusia, (Yogyakarta: Andi Offset, 2003), h. 135. 
Yusran, Rachmad Saleh Nasution: Evaluasi Kinerja Program Studi Ekonomi Syariah Fakultas Ekonomi dan Bisnis Islam IAIN Samarinda Pasca Akreditasi

\section{Manfaat Penilaian Kinerja}

Orang-orang yang berkecimpung dalam manajemen sumber daya manusia sependapat bahwa penilaian ini merupakan bagian penting dari seluruh proses kekaryaan karyawan yang bersangkutan.Manfaat yang diperoleh dari penilaian kinerja ini terutama menjadi pedoman dalam melakukan tindakan evaluasi bagi pembentukan organisasi yang sesuai dengan harapan.

Mangkuprawira menjelaskan manfaat penilaian kinerja ditinjau dari beragam perspektif pengembangan perusahaan, khususnya manajemen sumber daya manusia. ${ }^{13}$

Sedangkan Notoatmodjo mengemukakan bahwa ada tujuh manfaat penilaian kinerja yaitu peningkatan prestasi kerja, kesempatan kerja yang adil, kebutuhan-kebutuhan pelatihan pengembangan, penyesuaian kompensasi, keputusan-keputusan promosi dan demosi, kesalahankesalahan desain pekerjaan serta penyimpangan-penyimpangan proses rekruitmen dan seleksi. ${ }^{14}$

Manfaat penilaian kinerja adalah untuk penyesuaian kompensasi, keputusan penempatan dan pengembangan karir dan memberikan kesempatan kerja yang adil, sehingga karyawan dapat memperbaiki kinerjanya. Hal ini akan berdampak pada perbaikan perencanaan dan pengembangan organisasi untuk menghadapi tantangan masa depan.

\footnotetext{
${ }^{13}$ Syafri Mangkuprawira, Manajemen Sumber Daya Manusia Strategik, (Bogor: Ghalia Indonesia, 2003), h. 224-225.

${ }^{14}$ Notoatmodjo, Pengembangan Sumber Daya Manusia, (Jakarta: Rineka Cipta, 2011), h. 142-143.
} 
Yusran, Rachmad Saleh Nasution: Evaluasi Kinerja Program Studi Ekonomi Syariah Fakultas Ekonomi dan Bisnis Islam IAIN Samarinda Pasca Akreditasi

\section{Indikator Kinerja}

Kinerja adalah sesuatu yang seharusnya dapat dikuantitatifkan, sehingga dapat diukur. Pengukuran kinerja ini penting untuk mengetahui sejauh mana kinerja individu atau organisasi secara keseluruhan dalam mencapai tujuan-tujuan individual atau organisasi. Individu atau organisasi bisa dikatakan berhasil dalam mencapai tujuannya apabila ditunjukkan dengan kinerja yang tinggi. Kinerja bisa diukur dengan menggunakan indikator-indikator kinerja.

Indikator kinerja menurut Sudarmanto adalah aspek-aspek yang menjadi ukuran dalam menilai kinerja. ${ }^{15}$ Berikut ini adalah beberapa pendapat tentang indikator kinerja.

Wibowo mengadopsi pendapat Hersey, Blanchard, dan Johnson dalam menjelaskan bahwa terdapat tujuh indikator kinerja; yaitu (1) tujuan, (2) standar, (3) umpan balik, (4) Alat atau sarana, (5) kompetensi, (6) motif, dan (7) peluang. ${ }^{16}$

\section{Akreditasi Perguruan Tinggi}

Akreditasi merupakan salah satu bentuk penilaian (evaluasi) mutu dan kelayakan institusi perguruan tinggi atau program studi yang dilakukan oleh organisasi atau badan mandiri di luar perguruan tinggi. Bentuk penilaian mutu eksternal yang lain adalah penilaian yang berkaitan dengan akuntabilitas, pemberian izin, pemberian lisensi oleh badan tertentu.

15 Sudarmanto, Manajemen Sumber Daya Manusia: Teori dan Praktik, (Bandung: Remaja Rosdakarya, 2009), h. 21.

${ }^{16}$ Wibowo, Manajemen Kinerja, (Jakarta: Rajawali Pers, 2013), h. 102-104. 
Berbeda dari bentuk penilaian mutu lainnya, akreditasi dilakukan oleh pakar sejawat dan mereka yang memahami hakikat pengelolaan perguruan tinggi sebagai Tim atau Kelompok Asesor. Keputusan mengenai mutu didasarkan pada penilaian terhadap berbagai bukti yang terkait dengan standar yang ditetapkan dan berdasarkan nalar dan pertimbangan para pakar sejawat (judgments of informed experts). Buktibukti yang diperlukan termasuk laporan tertulis yang disiapkan oleh institusi perguruan tinggi yang akan diakreditasi yang diverifikasi dan divalidasi melalui kunjungan para pakar sejawat ke tempat kedudukan perguruan tinggi.

Akreditasi merupakan suatu proses dan hasil. Sebagai proses, akreditasi merupakan suatu upaya BAN-PT untuk menilai dan menentukan status mutu institusi perguruan tinggi berdasarkan standar mutu yang telah ditetapkan. Sebagai hasil, akreditasi merupakan status mutu perguruan tinggi yang diumumkan kepada masyarakat.

\section{Standar Akreditasi Institut Perguruan Tinggi}

Standar akreditasi adalah tolok ukur yang harus dipenuhi oleh institusi perguruan tinggi. Suatu standar akreditasi terdiri atas beberapa parameter (elemen penilaian) yang dapat digunakan sebagai dasar untuk mengukur dan menetapkan mutu dan kelayakan perguruan tinggi untuk menyelenggarakan program-programnya.

Asesmen kinerja perguruan tinggi didasarkan pada pemenuhan tuntutan standar akreditasi. Dokumen akreditasi perguruan tinggi yang dapat diproses harus telah memenuhi persyaratan awal (eligibilitas) yang ditandai dengan adanya izin penyelenggaraan perguruan tinggi dari 
Yusran, Rachmad Saleh Nasution: Evaluasi Kinerja Program Studi Ekonomi Syariah Fakultas Ekonomi dan Bisnis Islam IAIN Samarinda Pasca Akreditasi

pejabat yang berwewenang, dan memiliki minimal 75\% program studi yang masih berstatus terakreditasi dari semua program studi pada semua tingkat yang ada di perguruan tinggi terkait.

\section{A. Metode Penelitian}

Penelitian ini adalah penelitian lapangan (field research), ${ }^{17}$ dengan obyek penelitian pejabat dan dosen pada Jurusan Ekonomi Syariah Fakultas Ekonomi dan Bisnis Islam IAIN Samarinda. Pengumpulan atau penggalian data dilakukan dengan metode triangulasi yang memadukan kualitatif dan kuantitatif dengan basis pada metode observasi, ${ }^{18}$ wawancara, ${ }^{19}$ dokumentasi, ${ }^{20}$ serta angket.

Populasi dalam penelitian ini adalah seluruh civitas akademika di Jurusan Ekonomi Syariah Fakultas Ekonomi dan Bisnis Islam IAIN

17 Yaitu suatu penelitian yang dilakukan secara intensif, terperinci, dan mendalam terhadap suatu objek tertentu dengan mempelajarinya sebagai suatu kasus. Lihat Handari Nawawi, Metodologi Penelitian Bidang Sosial, cet. 1, (Yogyakarta: Gadjah Mada University Press, 1995), h. 72.

${ }^{18}$ Metode observasi disebut juga metode pengamatan, yaitu cara pengumpulan data dengan melakukan pengamatan, dan pencatatan secara cermat dan sistematik secara langsung ataupun tidak langsung. Lihat Soeratno dan Lincoln Arsyad, Metodologi Penelitian untuk Ekonomi dan Bisnis,(Yogyakarta: UPP AMP YKPN, 1993), h. 89. Husein Umar, Riset Pemasaran dan Perilaku Konsumen, (Jakarta: Gramedia, 2000), h. 169.

${ }^{19}$ Wawancara atau interview dilakukan dengan cara terbuka (overt) dan tidak tertutup (convert). Sifat pertanyaan tidak terstruktur (unstructured interview), dan menekankan pada pendalaman (probing) yang terkait dengan kasus saja. Lihat Moleong, Metode, hlm. 136-139 dan Koentjaraningrat, "Metode Wawancara", dalam Koentjaraningrat (ed.), Metode-Metode Penelitian Masyarakat, (Jakarta: Gramedia, 1991), h. 138-140.

${ }^{20}$ Penggunaan dokumentasi diperlukan bagi peneliti untuk menunjang validitas dan efektifitas dalam pengambilan data, yaitu dokumentasi Prodi Muamalah Jurusan Syariah dan Ekonomi Islam IAIN Samarinda. Metode data berupa dokumentasi lihat Noeng Muhajir, Metode Penelitian Kualitatif, (Yogyakarta: Rake Sarasin, 1998), h. 6263.

Al Qalam: Jurnal Ilmiah Keagamaan dan Kemasyarakatan Vol. 14, No. 1, Januari-Juni 2020 
Samarinda. Teknik pengambilan sampel yang digunakan adalah strata sample (stratified sampling). Menurut Siregar, stratified sampling adalah salah satu teknik pengambilan sampel dengan populasi yang memiliki tingkatan dan setiap tingkatan memiliki karakteristik tersendiri. ${ }^{21}$

Adapun metode analisis yang digunakan dalam penelitian adalah metode analisis deskriptif yaitu mengkaji antara pelaksanaan respon mahasiswa terhadap kualtias pelayanan akademik yang diterapkan pada Mahasiswa Jurusan Ekonomi Syariah Fakultas Ekonomi dan Bisnis Islam IAIN Samarinda dengan teori yang relevan dengan penelitian ini.

a. Uji Validitas (Kesahihan) Instrumen Penelitian

Validitas adalah tingkat ketepatan penggunaan alat terhadap suatu gejala, yang menunjukkan sejauh mana suatu alat pengukur itu mengukur sesuatu yang ingin diukur.

Uji validitas dilakukan untuk mengetahui apakah item-item yang tersaji dalam kuesioner benar-benar mampu mengungkapkan dengan pasti apa yang akan diteliti.

$$
\mathrm{r}=\frac{\mathrm{n}\left(\sum \mathrm{XY}\right)-\left(\sum X \cdot \sum Y\right)}{\sqrt{\left[n \sum X^{2}-\left(\sum X^{2}\right)\right]\left[n \sum Y^{2}-\left(\sum Y\right)^{2}\right]}}
$$

Keterangan :

$\mathrm{r}$ : koefisien korelasi product moment

$\mathrm{n}$ : banyaknya sampel

$\mathrm{X}$ : nilai dari item

Y: nilai dari total item h.31.

${ }^{21}$ Syofian Siregar, Metode Penelitian Kuantitatif, (Jakarta: Kencana, 2013), 
Yusran, Rachmad Saleh Nasution: Evaluasi Kinerja Program Studi Ekonomi Syariah Fakultas Ekonomi dan Bisnis Islam IAIN Samarinda Pasca Akreditasi

\section{Uji Reliabilitas}

Reliabilitas adalah tingkat kestabilan dari suatu alat ukur dalam mengukur suatu gejala. Hasilnya menunjukkan seberapa jauh suatu alat pengukur dapat dipercaya atau dapat diandalkan. Untuk mengukur reliabilitas digunakan rumus Alpha Cronbach

$$
r_{11}=\left[\frac{k}{k-1}\right]\left[1-\frac{\sum \alpha^{2} b}{\alpha^{2} t}\right]
$$

Keterangan

$$
\begin{array}{ll}
\mathrm{r} 11 & : \text { reliabilitas instrumen } \\
\mathrm{k} & : \text { banyaknya butir pertanyaan } \\
\alpha & : \text { varian total } \\
\sum \alpha 2 \mathrm{~b} & : \text { jumlah varian butir }
\end{array}
$$

\section{B. Temuan dan Pembahasan}

Hasil penelitian evaluasi kinerja program studi ekonomi syariah sebelum dan pasca akreditasi ini meliputi: perkembangan jumlah mahasiswa, perkembangan jumlah penelitian dan perkembangan jumlah pengabdian masyarakat, penilaian kinerja prodi sebelum akreditasi, penilaian kinerja prodi setelah akreditasi, dan pengaruh akreditasi terhadap kinerja prodi. Penelitian ini menggunakan kuesioner yang disebar ke seluruh pejabat di lingkungan Fakultas Ekonomi dan Bisnis Islam IAIN Samarinda dan dosen yang mengajar di Jurusan Ekonomi Syariah Fakultas Ekonomi dan Bisnis Islam IAIN Samarinda. Jumlah dosen baik tetap maupun tidak tetap yang mengajar di Jurusan Ekonomi Syariah adalah 30 orang, terdiri dari 15 orang dosen tetap PNS dan Non PNS, dan 15 orang 
Yusran, Rachmad Saleh Nasution: Evaluasi Kinerja Program Studi Ekonomi Syariah Fakultas Ekonomi dan Bisnis Islam IAIN Samarinda Pasca Akreditasi

dosen luar biasa. Kuesioner disebar ke 30 responden tersebut dan termasuk di dalamnya pejabat terkait.

Dari hasil penyebaran kuesioner didapat informasi umum mengenai jenjang pendidikan responden, jumlah kelas yang diajarkan, jumlah mata kuliah yang diampu, dan lamanya masa kerja di Fakultas Ekonomi dan Ekonomi Bisnis Islam. Adapun hasilnya secara rinci digambarkan dalam diagram berikut.

Diagram 1

Jenjang Pendidikan

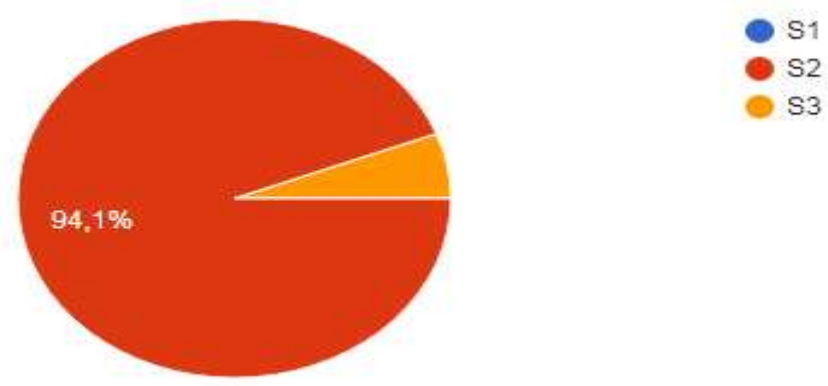

Hasil data Diagram 1 menunjukkan bahwa sebesar 94,1\% memiliki gelar akademik strata dua S2 dan sisanya sebesar 5,9\% memiliki jenjang pendidikan doktor (S3). Hasil ini menggambarkan telah terpenuhinya salah satu kriteria dosen dalam mengajar pada program strata satu yaitu berpendidikan minimal strata dua (S2).

\section{Diagram 2}

Jumlah Kelas yang diajar

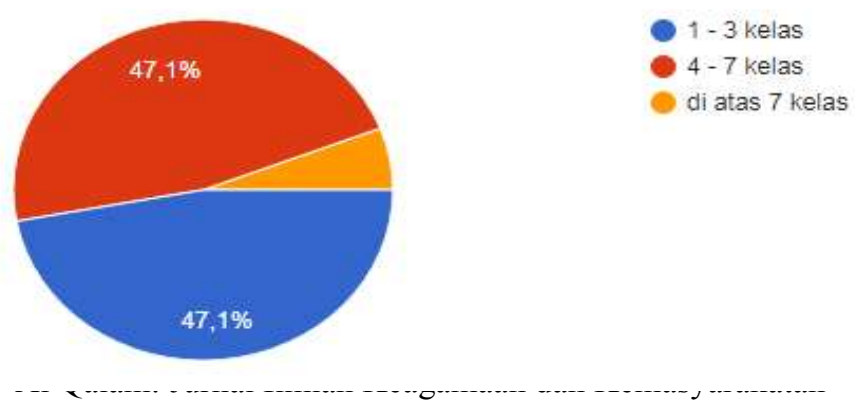

Vol. 14, No. 1, Januari-Juni 2020 
Yusran, Rachmad Saleh Nasution: Evaluasi Kinerja Program Studi Ekonomi Syariah Fakultas Ekonomi dan Bisnis Islam IAIN Samarinda Pasca Akreditasi

Hasil diagram 3 menunjukkan 47,1 \% dari 30 responden mengajar 1 sampai 3 kelas dalam satu semester, dan 47,1\% responden mengajar 4 sampai 7 kelas, sementara sisanya 5,8\% responden mengajar di atas 7 kelas.

\section{Diagram 4}

Masa Kerja di Fakultas Ekonomi dan Bisnis Islam IAIN Samarinda

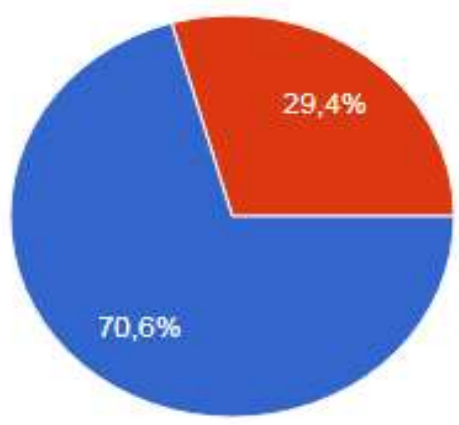

1 - 3 Tahun

Di atas 3 Tahun

Masa kerja sebagian besar responden adalah di bawah 3 tahun yaitu sebesar 70,6\% responden, sedangkan sisanya sebesar 29,4\% telah mengajar lebih dari 3 tahun di Fakultas Ekonomi dan Bisnis Islam IAIN Samarinda.

\section{Diagram 5}

Jumlah Matakuliah yang Diampu

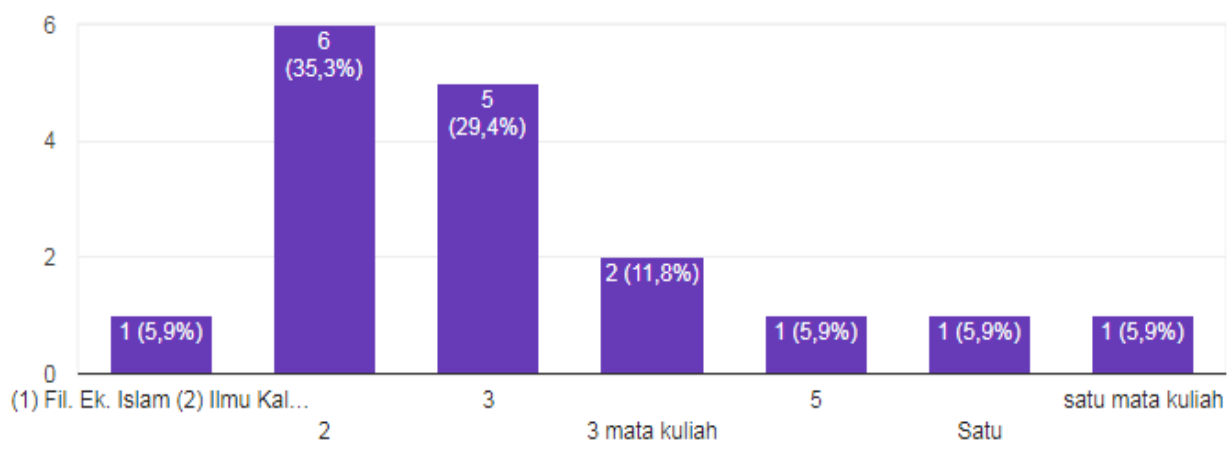


Yusran, Rachmad Saleh Nasution: Evaluasi Kinerja Program Studi Ekonomi Syariah Fakultas Ekonomi dan Bisnis Islam IAIN Samarinda Pasca Akreditasi

Sebagian besar dosen mengampu lebih dari 6 mata kuliah yaitu sebesar $64,7 \%$. Selebihnya sebesar 35,3\% mengajar dibawah 5 mata kuliah tiap semesternya. Hasil ini menunjukkan masih banyak dosen tetap yang mengampu lebih dari 6 mata kuliah dengan status memegang jabatan struktural. Indikasi kelebihan beban mengajar yang masih sering terjadi dan kurang efektif bagi mereka yang memegang jabatan struktural.

Umpan Balik pada SDM: Kinerja yang baik dan buruk di seluruh organisasi mengindikasikan bagaimana baiknya fungsi departemen SDM diterapkan. ${ }^{22}$ Indikator kinerja menurut Sudarmanto adalah aspek-aspek yang menjadi ukuran dalam menilai kinerja. ${ }^{23}$ Berikut ini adalah beberapa pendapat tentang indikator kinerja.

Wibowo mengadopsi pendapat Hersey, Blanchard, dan Johnson dalam menjelaskan bahwa terdapat tujuh indikator kinerja; yaitu (1) tujuan, (2) standar, (3) umpan balik, (4) Alat atau sarana, (5) kompetensi, (6) motif, dan (7) peluang. ${ }^{24}$

Sesuai dengan pendapat Mangkunegara bahwa kinerja yaitu "hasil kerja secara kualitas dan kuantitas yang dicapai oleh seorang pegawai dalam melaksanakan tugasnya sesuai dengan tanggung jawab yang diberikan kepadanya". Ada tiga variabel yang dapat mempengaruhi kinerja, yaitu: variabel orang, variabel tugas, dan variabel lingkungan. Variabel orang termasuk atribut yang dimiliki seseorang sebelum melakukan tugas seperti konten pengetahuan, pengetahuan organisasi,

\footnotetext{
${ }^{22}$ Syafri Mangkuprawira, Manajemen Sumber Daya Manusia Strategik, (Bogor: Ghalia Indonesia, 2003), h. 224-225.

23 Sudarmanto, Manajemen Sumber Daya Manusia: Teori dan Praktik, (Bandung: Remaja Rosdakarya, 2009), h. 21.

${ }^{24}$ Wibowo, Manajemen Kinerja, (Jakarta: Rajawali Pers, 2013), h. 102-104.
} 
Yusran, Rachmad Saleh Nasution: Evaluasi Kinerja Program Studi Ekonomi Syariah Fakultas Ekonomi dan Bisnis Islam IAIN Samarinda Pasca Akreditasi

kemampuan, kepercayaan diri, gaya kognitif, motivasi intrinsik, nilai-nilai budaya. Variabel tugas termasuk faktor-faktor yang bervariasi baik di dalam maupun di luar tugas, seperti kompleksitas, format presentasi, pengolahan dan respon modus siaga. Sementara itu, variabel lingkungan meliputi semua kondisi, keadaan, dan pengaruh di sekitar orang yang melakukan tugas tertentu, seperti tekanan waktu, akuntabilitas, tujuan yang telah ditetapkan dan umpan balik. ${ }^{25}$

Sedangkan sependapat dengan Nasucha dalam Fahmi "kinerja organisasi adalah sebagai efektivitas organisasi secara menyeluruh untuk memenuhi kebutuhan yang ditetapkan dari setiap kelompok yang berkenaan dengan usaha-usaha yang sistemik dan meningkatkan kemampuan organisasi secara terus menerus mencapai kebutuhannya secara efektif". Pengertian kinerja adalah suatu tingkat peranan anggota organisasi dalam mencapai tujuan-tujuan organisasi, peranan yang dimaksud adalah pelaksanaan suatu tindakan untuk menjalankan dan menyelesaikan tugas yang diberikan. ${ }^{26}$

Secara garis besar, sebagai bagian dari sistem akuntabilitas kinerja, siklus manajemen kinerja dibagi dalam lima fase atau lima tahap, yaitu: perencanaan kerja, implementasi, pengukuran kinerja dan evaluasi kinerja, pelaporan kinerja, dan audit kinerja. ${ }^{27}$

Dengan demikian bahwa kinerja merupakan tingkat keberhasilan keseluruhan pekerjaan selama periode tertentu dan hasil yang dicapai dari pekerjaan tersebut, yang berorientasi pada standar hasil kinerja, target atau

25 Anwar Prabu Mangkunegara, Evaluasi Kinerja Sumber Daya Manusia, (Bandung: Refika Aditama, 2005), h. 32.

${ }^{26}$ Fahmi Rahman, Manajemen..., h. 56.

${ }^{27}$ Moehariono, Kebijakan Kinerja Karyawan, (Yogyakarta: BPFE, 2012), h. 69. 
Yusran, Rachmad Saleh Nasution: Evaluasi Kinerja Program Studi Ekonomi Syariah Fakultas Ekonomi dan Bisnis Islam IAIN Samarinda Pasca Akreditasi

kriteria yang telah disepakati bersama. Demikian juga dengan sistem manajemen kinerja organisasi publik atau instansi pemerintah mengandung prosedur, langkah atau tahapan yang mengandung suatu siklus kinerja.

\section{Perkembangan Mahasiswa Sebelum dan Sesudah Akreditasi}

Salah satu indikator penilaian kinerja program studi adalah jumlah dan kualitas input mahasiswa. Beberapa indikator yang menunjukkan kualitas input mahasiswa yang mendukung kinerja program studi yaitu keketatan seleksi, masa studi dan indeks prestasi kelulusan (IPK). Keketatan seleksi dihitung dari rasio jumlah calon mahasiswa yang mendaftar dengan jumlah mahasiswa yang diterima, masa studi diperkirakan dari rasio jumlah input (mahasiswa yang masuk) dengan output (jumlah lulusan) 4 tahun kemudian. Berdasarkan data dokumentasi program studi ekonomi syariah didapat informasi perkembangan jumlah mahasiswa sebagai berikut:

\section{Tabel 1}

Perkembangan Jumlah Mahasiswa Ekonomi Syariah IAIN Samarinda

\begin{tabular}{c|c|c|c} 
No & Tahun & $\begin{array}{c}\text { Jumlah Mahasiswa } \\
\text { Masuk }\end{array}$ & $\begin{array}{c}\text { Jumlah Mahasiswa } \\
\text { Lulus }\end{array}$ \\
\hline 1 & 2014 & 105 & - \\
\hline 2 & 2015 & 87 & - \\
\hline 3 & 2016 & 105 & - \\
\hline 4 & 2017 & 163 & 23
\end{tabular}

Sumber Data: TIPD IAIN Samarinda 
Yusran, Rachmad Saleh Nasution: Evaluasi Kinerja Program Studi Ekonomi Syariah Fakultas Ekonomi dan Bisnis Islam IAIN Samarinda Pasca Akreditasi

Dari data tabel di atas terlihat pada tahun pertama pembukaan program studi ekonomi syariah menerima mahasiswa sejumlah 105 orang. Angka ini sempat mengalami penurunan di tahun kedua yaitu sebanyak 87 mahasiswa. Pada tahun 2016 akreditasi dilakukan dan mendapat nilai B. Setelah mendapat akreditasi dari BAN PT, jumlah mahasiswa mengalami peningkatan yang cukup signifikan yaitu sebesar lebih $50 \%$ pada tahun 2017 dan hamper mencapai 100\% di tahun 2018.

Prestasi kerja menurut Ruky disebut juga sebagai kinerja atau dalam bahasa Inggris disebut performance. Pada prinsipnya, ada istilah lain yang lebih menggambarkan pada prestasi dalam bahasa Inggris yaitu kata achievement. ${ }^{28}$ Penilaian kinerja adalah suatu penilaian yang dilakukan kepada pihak manajemen perusahaan baik karyawan maupun manajer yang selama ini telah melakukan pekerjaannya. Sedangkan Mathis dan Jackson mengatakan bahwa penilaian kinerja merupakan proses mengevaluasi seberapa baik karyawan mengerjakan pekerjaan mereka ketika dibandingkan dengan satu set standar, dan kemudian mengomunikasikan informasi tersebut. ${ }^{29}$ Orientasi penilaian adalah masa depan yang pada gilirannya memungkinkan organisasi meningkatkan kinerjanya. ${ }^{30}$

${ }^{28}$ Hariandja, Peformance Appraistal: Sistem yang tepat untuk Menilai Kinerja Karyawan dan Meningkatkan Daya Saing Perusahaan, (Jakarta: Grafindo Persada, 2005), h. 35.

${ }^{29}$ R.L Mathis \& J. H. Jackson, Human Resource Management: Manajemen Sumber Daya Manusia, Terj. Dian Angelia, (Jakarta: Salemba Empat, 2006), h. 65

${ }^{30}$ Sondang P. Siagian, Manajemen Stratejik, (Jakarta: Bumi Aksara, 2012), h. 41. 
Yusran, Rachmad Saleh Nasution: Evaluasi Kinerja Program Studi Ekonomi Syariah Fakultas Ekonomi dan Bisnis Islam IAIN Samarinda Pasca Akreditasi

\section{Perkembangan Jumlah Penelitian dan Pengabdian Masyarakat}

Indikator untuk mengukur kinerja program studi lainnya ditunjukkan oleh produktivitas, kualitas dan efektivitas karya-karya inovatif yang dihasilkan oleh dosen. Karya inovatif yang comparable (dapat dibandingkan) dengan perguruan tinggi lain adalah karya penelitian dan pengabdian kepada masyarakat. Produktivitas ditunjukkan oleh kuantitas/jumlah penelitian sedangkan kualitas diukur dari jumlah dana yang terserap dengan asumsi semakin besar jumlah dana yang diraih maka semakin berkualitas penelitian yang dihasilkan. Efektivitas dapat dilihat dari sumbangan atau pemanfaatan hasil penelitian tersebut oleh stakeholder/masyarakat.

Dalam penelitian ini, untuk menilai kinerja program studi ekonomi syariah pada standar penelitian dan pengabdian masyarakat digunakan indikator kuantitas judul penelitian. Hasil wawancara yang dilakukan dengan Dekan, para Pembantu Dekan, Ketua Jurusan, Sekretaris Jurusan, Kaprodi dan Dosen ekonomi syariah menunjukkan peningkatan dalam pendidikan dan pengajaran, penelitian dan pengabdian masyarakat pasca akreditasi. Hasil ini juga didukung dengan data yang didapat dari LP2M yang menunjukkan peningkatan jumlah peneliti pasca akreditasi.

Data perkembangan jumlah penelitian pada prodi ekonomi syariah sebelum akreditasi tahun 2014 dan sesudah akreditasi dapat ditunjukkan pada Tabel berikut: 
Yusran, Rachmad Saleh Nasution: Evaluasi Kinerja Program Studi Ekonomi Syariah Fakultas Ekonomi dan Bisnis Islam IAIN Samarinda Pasca Akreditasi

Tabel 2

Perkembangan Penelitian Prodi Ekonomi Syariah

\begin{tabular}{c|c|c} 
NO & TAHUN PENELITIAN & JUMLAH PENELITIAN \\
\hline 1 & 2014 & 6 \\
\hline 2 & 2015 & 6 \\
\hline 3 & 2016 & 6 \\
\hline 4 & 2017 & 7 \\
\hline 5 & 2018 & 15
\end{tabular}

Sumber: LP2M IAIN Samarinda

\section{Pengaruh Akreditasi Terhadap Kinerja Prodi Ekonomi Syariah}

Fokus penelitian ini adalah evaluasi kinerja untuk mengetahui adakah pengaruh akreditasi terhadap kinerja program studi ekonomi syariah. Untuk mengetahui pengaruh akreditasi terhadap kinerja prodi dilakukan dengan cara membandingkan kinerja program studi sebelum terakreditasi dan setelah terakreditasi. Kinerja prodi Ekonomi Syariah sebelum dan setelah/pasca akreditasi dinilai berdasarkan kuesioner persepsi responden terhadap kinerja program studinya sendiri. Untuk menginterpretasikan hasil analisis data, skor rerata dibuat menjadi 4 kategori, yaitu sangat baik, baik, sedang dan kurang dengan rentang skor sebagai berikut: 
Tabel 3

RATING SKOR RERATA BUTIR KINERJA

\begin{tabular}{l|l}
\multicolumn{1}{c|}{ Kategori } & \multicolumn{2}{c}{ Skor } \\
\hline Sangat Baik & $>4$ \\
\hline Baik & $3,0-3,9$ \\
\hline Sedang & $2,0-2,9$ \\
\hline Kurang & $1,0-1,9$
\end{tabular}

Berikut ini secara berturut-turut disajikan data tentang rata-rata kinerja prodi sebelum dan sesudah terakreditasi menurut seluruh responden. Dalam penyajian data ini juga dikemukakan pengaruh akreditasi terhadap kinerja prodi ekonomi syariah berdasarkan 100 butir instrument penilaian akreditasi, yang selanjuutnya diringkas menjadi tujuh instrument standar sebagai berikut :

Tabel 4 (lampiran 1)

Kinerja Prodi Ekonomi Syariah Sebelum dan Sesudah Akreditasi

\begin{tabular}{c|l|c|c|c} 
No & $\begin{array}{l}\text { Instrumen } \\
\text { Penilaian }\end{array}$ & $\begin{array}{c}\text { Skor rata2 } \\
\text { Responden } \\
\text { Sebelum } \\
\text { Akreditasi }\end{array}$ & $\begin{array}{c}\text { Skor Rata2 } \\
\text { Responden } \\
\text { Setelah } \\
\text { Akreditasi }\end{array}$ & $\begin{array}{c}\text { Pengaruh } \\
\text { Kinerja } \\
\text { Setelah } \\
\text { Akreditasi }\end{array}$ \\
\hline 1 & $\begin{array}{l}\text { Standar 1 Visi } \\
\text { Misi Tujuan dan }\end{array}$ & 2,5 & 3,1 & $24 \%$ \\
\hline 2 & $\begin{array}{l}\text { Sasaran } \\
\text { Standar 2 Tata } \\
\text { Pamong dan } \\
\text { Kepemimpinan }\end{array}$ & 2,8 & 3,1 & $9,3 \%$ \\
\hline 3 & $\begin{array}{l}\text { Standar r 3 } \\
\text { Mahasiswa } \\
\text { danLulusan }\end{array}$ & 2,4 & 2,9 & $25 \%$ \\
\end{tabular}


Yusran, Rachmad Saleh Nasution: Evaluasi Kinerja Program Studi Ekonomi Syariah Fakultas Ekonomi dan Bisnis Islam IAIN Samarinda Pasca Akreditasi

\begin{tabular}{l|l|c|c|c}
4 & $\begin{array}{l}\text { Standar 4 Sumber } \\
\text { Daya Manusia }\end{array}$ & 2,4 & 3,0 & $24 \%$ \\
\hline 5 & $\begin{array}{l}\text { Standar 5 } \\
\text { Kurikulum dan } \\
\text { Pembelajaran }\end{array}$ & 2,4 & 2,7 & $13 \%$ \\
\hline 6 & $\begin{array}{l}\text { Standar } \\
\text { Pembiayaan, } \\
\text { Sarana } \\
\text { Prasarana dan }\end{array}$ & 2,5 & 3,3 & $32 \%$ \\
\hline 7 & $\begin{array}{l}\text { Standar } \\
\text { Penelitian dan } \\
\text { Pengabdian } \\
\text { Masyarakat }\end{array}$ & 2,3 & 2,7 & $14,7 \%$ \\
\hline
\end{tabular}

Berdasar Tabel 4 di atas, dapat dianalisis penilaian kinerja pada prodi ekonomi syariah sebelum akreditasi menurut responden sebagai berikut:

a. Nilai kinerja prodi ekonom i syariah pada standar visi, misi, tujuan dan sasaran sebelum terakreditasi adalah 2,5 pada skor 4 .

b. Nilai kinerja prodi ekonomi syariah pada standar tata pamong dan kepemimpinan sebelum terakreditasi adalah sebesar 2,8 pada skor 4 .

c. Nilai kinerja prodi ekonomi syariah pada standar mahasiswa dan lulusan sebelum terakreditasi adalah 2,4 pada skor 4 .

d. Nilai kinerja prodi ekonomi syariah pada standar sumber daya manusia sebelum terakreditasi adalah 2,4 pada skor 4 .

e. Nilai kinerja prodi ekonomi syariah pada standar kurikulum dan pembelajaran sebelum terakreditasi adalah 2,4 pada skor 4 .

f. Nilai kinerja prodi ekonomi syariah pada standar pembiayaan, sarana dan prasarana serta SIM sebelum terakreditasi adalah 2,5 pada skor 4 . 
Yusran, Rachmad Saleh Nasution: Evaluasi Kinerja Program Studi Ekonomi Syariah Fakultas Ekonomi dan Bisnis Islam IAIN Samarinda Pasca Akreditasi

g. Nilai kinerja prodi ekonomi syariah pada standar penelitian, pengabdian masyarakat dan kerjasama sebelum terakreditasi adalah 2,3 pada skor 4.

Sementara hasil kinerja prodi ekonomi syariah pasca akreditasi berdasarkan 100 butir instrument penilaian akreditasi, yang selanjutnya diringkas dalam tujuh standar berdasarkan tabel 4 diatas dapat dijabarkan sebagai berikut :

a. Nilai kinerja prodi ekonomi syariah pada standar visi, misi, tujuan dan sasaran pasca terakreditasi adalah 3,1 pada skor 4 .

b. Nilai kinerja prodi ekonomi syariah pada standar tata pamong dan kepemimpinan pasca terakreditasi adalah 3,1 pada skor 4 .

c. Nilai kinerja prodi ekonomi syariah pada standar penelitian, pengabdian masyarakat dan kerjasama pasca terakreditasi adalah 2,9 pada skor 4.

d. Nilai kinerja prodi ekonomi syariah pada standar mahasiswa dan lulusan pasca terakreditasi adalah 3,0 pada skor 4 .

e. Nilai kinerja prodi ekonomi syariah pada standar sumber daya manusia pasca terakreditasi adalah 2,7 pada skor 4 .

f. Nilai kinerja prodi ekonomi syariah pada standar kurikulum dan pembelajaran pasca terakreditasi adalah 3,3 pada skor 4 .

g. Nilai kinerja prodi ekonomi syariah pada standar pembiayaan, sarana dan prasarana serta SIM pasca terakreditasi adalah 2,7 pada skor 4.

Analisis data pengaruh kinerja ekonomi syariah sebelum dan sesudah akreditasi dilihat dari peningkatan skor (gain score) dari setiap standar akreditasi. Hasil analisis tingkat pengaruh kinerja sebagaimana Tabel 4 di atas dapat dijabarkan sebagai berikut: 
Yusran, Rachmad Saleh Nasution: Evaluasi Kinerja Program Studi Ekonomi Syariah Fakultas Ekonomi dan Bisnis Islam IAIN Samarinda Pasca Akreditasi

a. Pengaruh kinerja prodi ekonomi syariah pada standar visi, misi, tujuan dan sasaran pasca terakreditasi adalah 24\% pada skor 4 .

b. Pengaruh kinerja prodi ekonomi syariah pada standar tata pamong dan kepemimpinan pasca terakreditasi adalah 9,3\% pada skor 4 .

c. Pengaruh kinerja prodi ekonomi syariah pada standar penelitian, pengabdian masyarakat dan kerjasama pasca terakreditasi adalah $25 \%$ pada skor 4.

d. Pengaruh kinerja prodi ekonomi syariah pada standar mahasiswa dan lulusan pasca terakreditasi adalah 24\% pada skor 4 .

e. Pengaruh kinerja prodi ekonomi syariah pada standar sumber daya manusia pasca terakreditasi adalah $13 \%$ pada skor 4 .

f. Pengaruh kinerja prodi ekonomi syariah pada standar kurikulum dan pembelajaran pasca terakreditasi adalah 32\% pada skor 4 .

g. Pengaruh kinerja prodi ekonomi syariah pada standar pembiayaan, sarana dan prasarana serta SIM pasca terakreditasi adalah 14,7\% pada skor 4.

Manajemen atau penyedia penilai untuk menilai kinerja tenaga kerja dengan cara membandingkan kinerja dengan kinerja atas uraian atau deskripsi pekerjaan dalam suatu periode tertentu biasanya setiap akhir tahun. ${ }^{31}$ Standar dalam penentuan tinggi rendahnya kompensasi serta administrasi bagi tenaga kerja. ${ }^{32}$

Kemudian menurut Faustino Cardoso Gomes tujuan penilaian kinerja secara umum dibedakan atas dua macam, yaitu untuk mereward

\footnotetext{
${ }^{31}$ Siswanto Sastrohadiwiryo, Manajemen Tenaga Kerja Indonesia: Pendekatan Administrasi dan Operasional, (Jakarta: Bumi Aksara, 2002), h. 231.

${ }^{32}$ Siswanto Sastrohadiwiryo, Manajemen Tenaga ..., h. 233.
} 
Yusran, Rachmad Saleh Nasution: Evaluasi Kinerja Program Studi Ekonomi Syariah Fakultas Ekonomi dan Bisnis Islam IAIN Samarinda Pasca Akreditasi

performasi sebelumnya (to reward past performance) dan untuk memotivasikan perbaikan performansi pada waktu yang akan datang (to motivate future performance improvement). ${ }^{33}$

Manfaat penilaian kinerja adalah untuk penyesuaian kompensasi, keputusan penempatan dan pengembangan karir dan memberikan kesempatan kerja yang adil, sehingga karyawan dapat memperbaiki kinerjanya. Hal ini akan berdampak pada perbaikan perencanaan dan pengembangan organisasi untuk menghadapi tantangan masa depan. '

Sedangkan Notoatmodjo mengemukakan bahwa ada tujuh manfaat penilaian kinerja yaitu peningkatan prestasi kerja, kesempatan kerja yang adil, kebutuhan-kebutuhan pelatihan pengembangan, penyesuaian kompensasi, keputusan-keputusan promosi dan demosi, kesalahankesalahan desain pekerjaan serta penyimpangan-penyimpangan proses rekruitmen dan seleksi. ${ }^{34}$

Dengan demikian dapat disimpulkan bahwa penilaian kerja merupakan suatu penilaian tentang kondisi kerja karyawan yang dilaksanakan secara formal dan dikaitkan dengan standar kerja yang telah ditentukan suatu instansi tertentu. Manfaat penilaian kinerja adalah untuk penyesuaian kompensasi, keputusan penempatan dan pengembangan karir dan memberikan kesempatan kerja yang adil, sehingga karyawan dapat memperbaiki kinerjanya. Hal ini akan berdampak pada perbaikan perencanaan dan pengembangan organisasi untuk menghadapi tantangan masa depan. Dengan adanya penilaian kinerja memberikan kesempatan

${ }^{33}$ Faustino Cardoso Gomes, Manajemen Sumber Daya Manusia, (Yogyakarta: Andi Offset, 2003), h. 135.

${ }^{34}$ Notoatmodjo, Pengembangan Sumber Daya Manusia, (Jakarta: Rineka Cipta, 2011), h. 142-143. 
bagi penilai untuk mengukur dan mengidentifikasikan kecenderungan kinerja karyawan untuk perbaikan manajemen selanjutnya serta kesempatan bagi penilai untuk menjelaskan tujuan dan prioritas penilai dengan memberikan pandangan yang lebih baik terhadap bagaimana karyawan dapat memberikan kontribusi yang lebih besar kepada perusahaan. Hasil penilaian kinerja sangat penting artinya bagi perusahaan dalam pengambilan keputusan tentang berbagai hal seperti: identifikasi kebutuhan program pendidikan dan pelatihan, rekrutmen, seleksi, program pengenalan, penempatan, promosi, sistem imbalan, dan berbagai aspek lainnya.

\section{Kesimpulan}

Kuesioner dalam penelitian ini terdiri dari 100 butir pertanyaan yang mencakup 7 unsur penelitian dalam akreditasi yang ditetapkan oleh BAN PT. Hasil analisis keseluruhan unsur penilaian tersebut menunjukkan terjadinya peningkatan di seluruh indikator penilaian kinerja, peningkatan terbesar ada pada indikator standar 6 yaitu pembiayaan, sarana perasarana sebesar 32\%. Menyusul standar 3 tentang mahasiswa dan lulusan dengan tingkat kinerja naik sebesar 25\% dan standar 4 tentang sumber daya dengan kenaikan sebesar 24\%.

Hasil analisis wawancara dan dokumentasi juga menunjukkan kenaikan di beberapa lini kegiatan seiring perkembangan jumlah mahasiswa yang lulus ujian masuk perguruan tinggi. Hal ini tidak terlepas dari salah satu faktor pendukung yaitu akreditasi lembaga Program Studi Ekonomi Syariah yang mendapatkan nilai B oleh asesor BAN PT. 
Yusran, Rachmad Saleh Nasution: Evaluasi Kinerja Program Studi Ekonomi Syariah Fakultas Ekonomi dan Bisnis Islam IAIN Samarinda Pasca Akreditasi

\section{Daftar Pustaka}

Ahmad Ruky, Sistem Manajemen Kinerja, (Jakarta: Gramedia Pustaka Utama, 2009)

Anwar Prabu Mangkunegara, Evaluasi Kinerja Sumber Daya Manusia, (Bandung: Refika Aditama, 2005)

Badan Akreditasi Nasional Perguruan Tinggi, Buku II: Standar dan Prosedur, (Jakarta: Badan Akreditasi Nasional Perguruan Tinggi, 2011), h. 1.

Bastian, Pengukuran Kinerja Sektor Publik, (Yogyakarta: Bale Anugerah, 2010), h. 43.

Fahmi Rahman, Manajemen Sumber Daya Manusia, (Bandung: Remaja Rosdakarya, 2009)

Faustino Cardoso Gomes, Manajemen Sumber Daya Manusia, (Yogyakarta: Andi Offset, 2003)

Handari Nawawi, Metodologi Penelitian Bidang Sosial, cet. 1, (Yogyakarta: Gadjah Mada University Press, 1995)

Hariandja, Peformance Appraistal: Sistem yang tepat untuk Menilai Kinerja Karyawan dan Meningkatkan Daya Saing Perusahaan, (Jakarta: Grafindo Persada, 2005)

Husein Umar, Riset Pemasaran dan Perilaku Konsumen, (Jakarta: Gramedia, 2000)

Koentjaraningrat, "Metode Wawancara", dalam Koentjaraningrat (ed.), Metode-Metode Penelitian Masyarakat, (Jakarta: Gramedia, 1991)

Michael Amstrong \& Baron, Manajemen Sumber Daya Manusia, terj. Sofyan dan Haryanto, (Jakarta: ElexMedia Komputindo, 2006), h. 15.

Moehariono, Kebijakan Kinerja Karyawan, (Yogyakarta: BPFE, 2012)

Noeng Muhajir, Metode Penelitian Kualitatif, (Yogyakarta: Rake Sarasin, 1998)

Notoatmodjo, Pengembangan Sumber Daya Manusia, (Jakarta: Rineka Cipta, 2011) 
Yusran, Rachmad Saleh Nasution: Evaluasi Kinerja Program Studi Ekonomi

Syariah Fakultas Ekonomi dan Bisnis Islam IAIN Samarinda Pasca Akreditasi

R.L Mathis \& J. H. Jackson, Human Resource Management: Manajemen Sumber Daya Manusia, Terj. Dian Angelia, (Jakarta: Salemba Empat, 2006)

Siswanto Sastrohadiwiryo, Manajemen Tenaga Kerja Indonesia: Pendekatan Administrasi dan Operasional, (Jakarta: Bumi Aksara, 2002)

Soeratno dan Lincoln Arsyad, Metodologi Penelitian untuk Ekonomi dan Bisnis,(Yogyakarta: UPP AMP YKPN, 1993)

Sondang P. Siagian, Manajemen Stratejik, (Jakarta: Bumi Aksara, 2012)

Stephen P. Robbins, Perilaku Organisasi, (Jakarta: Indeks Gramedia, 2006)

Sudarmanto, Manajemen Sumber Daya Manusia: Teori dan Praktik, (Bandung: Remaja Rosdakarya, 2009)

Syafri Mangkuprawira, Manajemen Sumber Daya Manusia Strategik, (Bogor: Ghalia Indonesia, 2003)

Syofian Siregar, Metode Penelitian Kuantitatif, (Jakarta: Kencana, 2013), h.31.

Wibowo, Manajemen Kinerja, (Jakarta: Rajawali Pers, 2013) 
Yusran, Rachmad Saleh Nasution: Evaluasi Kinerja Program Studi Ekonomi Syariah Fakultas Ekonomi dan Bisnis Islam IAIN Samarinda Pasca Akreditasi 